\title{
Credibility and Populism: The Economic policy of the Goulart Administrations in Brazil
}

\author{
Sérgio Marley Modesto Monteiro \\ Professor do Departamento de Ciências Econômicas da Universidade Federal do Rio Grande \\ do Sul (UFRGS) - Endereço para contato: Av. João Pessoa, 52, $3^{\circ}$ andar - Porto Alegre \\ Rio Grande do Sul - CEP 90040-000 - E-mail: sergio.monteiro@ufrgs.br
}

\section{Pedro Cezar Dutra Fonseca}

Professor do Departamento de Ciências Econômicas da Universidade Federal do Rio Grande do Sul (UFRGS) - Endereço para contato: Av. João Pessoa, 52, $3^{\circ}$ andar Porto Alegre, Rio Grande do Sul - CEP 90040-000 - Email: pedro.fonseca@ufrgs.br

Recebido em 02 de agosto de 2011 . Aceito em 29 de junho de 2012.

\begin{abstract}
The Goulart Administrations (1961-1964), which consisted of a parliamentary period and a presidential period, are considered typical examples of populism in Brazil. The literature usually defines economic policies advanced by these administrations as "hesitating", "irrational" or "ambiguous." We use a credibility model to argue that there is actually a consistent pattern in the manner in which economic policy was conducted. The credibility of the economic policies is defined to be the subjective probability that the government is following a monetary rule. Early on, the administrations enacted inflation-fighting measures. However, these policies were costly, and the administrations abandoned the course of austerity. As a result, their credibility was diminished, and attempts to achieve stabilization failed.
\end{abstract}

\section{Keywords}

populism, credibility, Brazil, João Goulart

\section{JEL Classification}

N16

\section{Resumo}

O governo Goulart (1961-1964), em suas fases parlamentarista e presidencialista, é considerado um exemplo típico do populismo no Brasil. A literatura sobre o período costuma definir a política econômica como hesitante, irracional ou ambígua. Neste trabalho, utiliza-se um modelo de credibilidade para explicar a condução da política econômica nas duas fases do governo. A credibilidade é definida como a probabilidade subjetiva com que os agentes avaliam o compromisso do governo para com as medidas de estabilidade por ele anunciadas, formalizadas por uma regra monetária. Nas duas fases o governo inicia com medidas de combate à inflação. À medida que 
o tempo passa, como resultado dos custos associados a esta política, a austeridade é abandonada, a credibilidade diminui e as tentativas de estabilização falham.

Palavras-Chave

populismo, credibilidade, Brasil, João Goulart

\section{Introduction}

The Goulart Administrations (1961-1964), which included a parliamentary and a presidential period, are usually considered typical examples of populism in Brazil. Populism is a phenomenon that has been present in several Latin American countries since the 1930s. The meaning, the historical motivations and the different manifestations of populism are subjects of intense debate, which has prevented a consensus conceptualization from forming; however, there are common traits that are widely mentioned by most analysts. These analysts usually highlight markedly political phenomena, such as the existence of charismatic leadership, a direct relationship between this leadership and the people, the dismissal of intermediaries, the redistributive rhetoric and the symbiosis between demagogical and authoritarian political practices. Dornbusch and Edwards (1991, p.9) define "economic populism" as "an approach to economics that emphasizes growth and income redistribution and deemphasizes the risks of inflation and deficit finance, external constraints, and the reaction of economic agents to aggressive nonmarket policies." The authors consider the most important characteristic of populist government to be "policymakers that explicitly reject the conservative paradigm and ignore the existence of any type of constraints on macroeconomic policy" (p.9). However, an analysis of the economic policies of the Goulart Administrations allows us to detect certain patterns that may help clarify their behavior in terms of populism and better understand the populist phenomenon in terms of economics. More specifically, we will focus on inflation-fighting and its short-term conflict with the proposals for policy favoring rapid economic growth.

The context in which Goulart took office is very important in understanding his administrations' actions. He faced rising inflation and a slowdown in GDP growth. These issues were accompanied by an aggravated status of foreign accounts with a deficit in the balance 
of payments, as well as with difficulties attracting foreign capital and accumulating domestic savings. From a political standpoint, Goulart faced difficulty even taking office due to a radical atmosphere in which a portion of the military and civil opposition actually proposed dismantling the constitutional rules. Despite Goulart's attempts to broaden his support base by employing a moderate and conciliatory voice, the nation's economic and political crises deepened. The increasing radicalization culminated in a military coup against Goulart.

The unstable political environment in which these administrations operated led to economic policies labeled as "hesitating", "irrational" and "ambiguous"; the implication is that those policies were completely erratic and illogical. In part, these difficulties of the Goulart government should be blamed on the international situation at the time. The period was marked by polarization resulting from the Cold War; this polarization had strong repercussions in Latin American countries, especially after the intensification of the conflict between Cuba and the United States after 1961. Several authors, such as Skidmore (1976), Ianni (1986), Flag (2001), Fonseca (2003), Bastos (2011) and Loureiro (2012) explored Goulart's foreign policy, albeit using different approaches. It is noteworthy that his foreign policy sometimes turned away from the United States (especially in the last months of his presidency, when there was an increase in radical nationalism) and sometimes signaling for cooperation; the conciliatory era was mainly a result of Brazil's need for loans to address growing balance of payments deficits. This positioning of the Goulart government is often cited by the literature as an example of "populism", which, in turn, influenced the government's credibility in conducting domestic economic policy. We will demonstrate the presence of a regular pattern in the government's economic policy, mainly relating to the conflict between inflation versus growth; in doing so, we will divide the Goulart Administrations into two periods: the parliamentary and presidential years. We conclude that the government's behavior during the two periods stem from the same strategy. Initially, the government was attempting to convince private agents that the priority was fighting inflation; in particular, the government proposed strict policies inspired by orthodoxy and a need to balance the public accounts. Economic development was always cited as the ultimate goal. As time passed, however, the priority placed on stabilization gradually became less clear. The go- 
vernment had no success fighting inflation, and its credibility was shaken. At this point, the government began making contradictory decisions, both for and against stability. This oscillating and hesitating policy helped to further erode the administrations' credibility, and they eventually abandoned any attempt to promote stability; their policies almost exclusively targeted growth in a last attempt to broaden the government's support base and legitimacy.

\section{The Populist Pattern of Economic Policy}

\subsection{Economic Policy and Credibility}

The empirically observed pattern in the economic policies in the two periods of the Goulart Administrations can be modeled to reveal the underlying logic. We do not attempt to test whether these were populist administrations. On the contrary, we take this as given, citing the specialized literature, especially within political science. Assuming this previous analysis is adequate, the proper methodological procedure approaches the question of whether there was in fact an economic policy pattern that we might call "populist" during these periods; in particular, we look for empirical evidence to help us understand how the populist phenomenon may have manifested itself in this environment.

According to Dornbusch and Edwards (1990), the populist paradigm in economics is characterized by four phases. During the first phase, production levels, real wages and the employment growth rate are high. An expansion in demand is counterbalanced by diminishing inventories and an increase in exports, which relieves the impact on prices. The financing of imports may occur through a reduction in reserves or a default on foreign payments. In the second phase, bottlenecks in production start to emerge. Inventories continue to decrease and price realignments, exchange control, devaluation and/or protectionism are necessary. Inflation simultaneously rises, although wages remain high and the public deficit worsens. In the third phase, insufficient supply of goods and services, acceleration in inflation and exchange rate problems lead to capital flight and a demonetization of the economy. The public deficit becomes even larger and real wages fall. During this phase, policies become unsta- 
ble. In the final phase, a new administration implements orthodox stabilization policies.

This sequence does not seem to adequately describe economic policy during the Goulart Administrations. As discussed in Persson and Tabellini (1995), the traditional approach of framing government decisions as permanent has given way to approaches that describe economic policy as the result of a strategic interaction between the government and the private sector. In this sense, a game-theoretic approach helps frame the pattern observed in the two Goulart Administrations as an equilibrium of the relevant "political games."

Following Barro (1986), let $z_{t}$ be the government's cost function, which depends on current inflation $\pi_{t}$ and surprise inflation $\left(\pi_{t}-\pi_{t}^{e}\right)$, where $\pi_{t}^{e}$ is the inflation expected by the public.

$$
z_{t}\left(\pi_{t}, \pi_{t}-\pi_{t}^{e}\right)=(a / 2) \pi_{t}^{2}-b\left(\pi_{t}-\pi_{t}^{e}\right)
$$

The coefficients $a$ and $b$ are positive, which means that the costs increase with current inflation $\pi_{t}$ and decrease with surprise inflation $\left(\pi_{t}-\pi_{t}^{e}\right)$. Surprise inflation is beneficial to the government because unanticipated monetary expansions may lead to an increase in economic activity; this increased activity lowers the unemployment rate, which is consistent with the definition of populism. This result can be obtained if we assume the existence of a Phillips curve along which the government can trade off inflation and unemployment.

The government attempts to minimize the expected present value of the costs, which is given by:

$$
E\left[z_{t}+z_{t+1} /(1+r)+\ldots+z_{T} /(1+r)^{T-t}\right],
$$

where $r>0$ is the exogenous, constant discount rate and $T$ is the terminal period.

In determining the equilibrium, Barro assumes two rules for the government's behavior. In the first rule, the government is committed to an inflation goal, so that $\pi_{t}^{e}=\pi_{t}$ and the level of inflation

\footnotetext{
1 We assume that the economic policy decisions are the result of a problem of strategic rational choice in which the government and the private sector each maximize an objective function subject to constraints.
} 
that minimizes costs is $\pi_{t}=0$ in all periods. The government's cost in each period is $z(0,0)=0$. In the second situation, the government acts discretionarily, taking the public's present and future inflation expectation as given. In this case, there will be a value for the inflation rate in $t$ that minimizes the cost, given by:

$$
\pi_{t}^{m}=b / a .
$$

The public, as a rational player, also solves the government's minimization problem and chooses $\pi_{t}^{e}=\pi_{t}^{m}=b / a$. Therefore, the Nash equilibrium of the model is characterized by zero surprise inflation. The cost to the government is:

$$
z_{t}=z^{m}=z\left(\pi_{t}, 0\right)=(1 / 2) b^{2} / a>0 .
$$

We can see that there is a higher cost to a government following the discretionary policy than a policy committing to an inflation target.

In the next stage of the analysis, we model the public as uncertain of the type of administration it is facing. Type 1 is strong; that is, it is committed to the non-inflationary goal. Type 2 is weak; that is, it has no capacity to make such a commitment and minimizes the expected current value of the costs. The government knows what its type is; however, the public does not know what type of government it is dealing with and must identify the type based only on the government's decisions. The fact that the public does not know the type of government it is dealing with allows the weak government to manipulate its reputation: it could pretend to be strong by choosing $\pi_{t}=0$. By doing so, it tries to reduce the public's inflation expectation, thus minimizing its costs. The time period for which the administration is in office is finite, lasting from 0 to $T$. In the final period $T$, which is common knowledge, the weak government does not have any more incentive to signal that it is strong: it chooses $\pi_{t}=\pi^{m}=b / a$.

Following Barro, let $p_{t}$ be the probability that a weak government chooses $\pi_{t}=0$, under the condition that the choice in the previous periods has been non-inflationary. Let $\alpha_{t}$ be the public's subjective probability in period $t$ that the government is of the strong type, where $\alpha_{0}$ is common knowledge. Let $p_{t}^{p}$ be the perception the public holds with regard to the value of $p_{t}$. 
If the result in period $t$ is $\pi_{t}=0$, there are two possibilities: either the government is of the strong type (with probability $\alpha_{t}$ ), or it is of the weak type (with probability $1-\alpha_{t}$ ) and is pretending (with probability $p_{t}$ ). The result $\pi_{t}=\pi_{t}^{m}$ will arise if the government is of the weak type (probability $1-\alpha_{t}$ ) and is not pretending to be strong (probability 1 $p_{t}$ ). Thus, the expected inflation in period $t$ is given by:

$$
\pi_{t}^{e}=\pi_{t}^{m}\left(1-\alpha_{t}\right)\left(1-p_{t}^{p}\right),
$$

which is the best forecast for $\pi_{t}$, given $\alpha_{t}$ and $p_{t}^{p}$. If the public observes $\pi_{t}=0$, it updates its beliefs regarding the government's reputation in the next period according to Bayes' rule:

$$
\begin{gathered}
\alpha_{t+1}=\operatorname{Prob}\left(\text { type } 1 \mid \pi_{t}, \pi_{t-1}, \ldots=0\right) \\
\alpha_{t+1}=\left[\operatorname{Prob}\left(\text { type } 1 \mid \pi_{t-1}, \ldots=0\right) .\right. \\
\left.\operatorname{Prob}\left(\pi_{t}=0 \mid \text { type } 1\right)\right] / \operatorname{Prob}\left(\pi_{t}=0 \mid \pi_{t-1}, \ldots=0\right) \\
\alpha_{t+1}=\alpha_{t} /\left[\alpha_{t}+\left(1-\alpha_{t}\right) p_{t}^{p}\right] .
\end{gathered}
$$

This expression indicates that if the public observes $\pi_{t}=0$, the government's reputation improves in the next period.

Under these conditions, Barro identifies two equilibrium intervals. In the first interval, $(0, \tau-1)$, the weak government mimics the strong government by choosing $\pi_{t}=0$ in an attempt to reduce the public's expectation of inflation. The government then profits from surprise inflation in the future. In this interval, there is no information gathering about the type of government because the public knows that both types can choose $\pi_{t}=0$ and $\alpha_{t}$ remains constant.

In the second interval, $(\tau, T-1)$, the weak government randomizes, choosing $\pi_{t}=0$ with probability $p_{t}$ and $\pi_{t}=b / a$ with probability $1-p_{t}$. In this interval, $\alpha_{t}$ is updated according to Bayes' rule. If the government chooses $\pi_{t}=0, \alpha_{t+1}$ is increasing and $p_{t}$ is decreasing. The intuition behind this result is that, as the administration approaches its end, the gain obtained by low inflation offsets the advantage of today's inflation and makes the government indifferent between inflation and no inflation. 
The condition that supports policy randomization is formulated by Barro as follows:

$z\left(0,-\pi_{t}^{e}\right)-z\left(\pi_{t}^{m}, \pi_{t}^{m}-\pi_{t}^{e}\right)=[1 /(1+r)] \cdot\left[z^{m}-z\left(\pi_{t+1}^{m}, \pi_{t+1}^{m}-\pi_{t+1}^{e}\right)\right]$.

On the left side of the equation, we have the government's temptation to inflate today, choosing $\pi_{t}=\pi_{t}^{m}$ instead of $\pi_{t}=0$. On the right side, we see what Barro referred to as "enforcement power", which represents the gain from postponing high inflation.

Combining the functional form (1) of the government's cost function with Expression (6), the trajectory of expected inflation in the interval $(\tau+1, T)$, we obtain:

$$
\pi_{t}^{e}=[(1-r) / 2] \cdot(b / a)
$$

Combining this result with (4), we obtain:

$$
\left(1-\alpha_{t}\right)\left(1-p_{t}\right)=(1-r) / 2
$$

In (8), we see that an increase in $\alpha_{t}$ is accompanied by a fall in $p_{t}$; that is, the better the reputation acquired by a weak government, the lower the probability that it chooses $\pi_{t}=0$. The equilibrium trajectory of $\alpha_{t}$ and $p_{t}$ is obtained by combining (8) and (5):

$$
\alpha_{t}=[(1+r) / 2]^{T+1-t}
$$

$p_{t}=\left\{[(1+r) / 2]-[(1+r) / 2]^{T+1-t}\right\} /\left\{1-[(1+r) / 2]^{T+1-t}\right\}$

for $\tau+1 \leq t \leq T$. The trajectories of the equilibrium show that $\alpha_{t}$ increases over time, while $p_{t}$ diminishes. The value of $T-\tau$, the length of the interval in which randomization occurs, is given by:

$$
T-\tau=\operatorname{int}\left\{\log \left(\alpha_{0}\right) / \log [(1+r) / 2]\right\}
$$

The main results of the model can be summarized by the analysis of the equilibrium trajectories of $\alpha_{t}$ and $p_{t}$. In the first interval, $(0, \tau$ $-1)$, the probability that the weak government chooses not to inflate is $100 \%\left(p_{t}=1\right)$, the subjective probability that the public assigns to 
the possibility of dealing with a strong government is constant $\left(\alpha_{t}=\right.$ $\left.\alpha_{0}\right)$ and the expected inflation is low $\left(\pi_{t}^{e}=\pi_{t}=0\right)$. The range of this interval depends on the final period $(T)$, the initial public subjective probability $\left(\alpha_{0}\right)$ and the time discount rate $(r)$, all of which are of common knowledge. In period $\tau$, there is a slight decline in $p_{t}$, but $\alpha_{t}$ remains constant. From $\tau+1$ forward, $p_{t}$ decreases and $\alpha_{t}$ increases. Along the entire trajectory, although the public observes low inflation, the expected inflation $\pi_{t}^{e}$ is constant. This occurs even though the low inflation improves the government's reputation $\left(\alpha_{t+1}>\alpha_{t}\right)$ because the fall in $p_{t}$ offsets the effect on the public's expectation of inflation; this tension makes any attempt to reduce inflationary expectations through the reputation mechanism futile. At time $T$, the value of $p_{t}$ is zero because the government has no more incentive to pretend to be strong. We observe that the maintenance of a low level of inflation by a strong government in the face of a constant $\pi_{t}^{e}$ will result in economic recession. As we will outline in the next section, Barro's model provides a general description of the economic policy during the Goulart Administrations.

\subsection{Measuring Credibility}

Despite being one of the main lines of recent research in macroeconomic theory, empirical knowledge about credibility is still quite limited. Blackburn and Christensen (1989, p.36) show some of the problems that occur regarding the notion of credibility. First, they mention the necessity of using proxy variables to measure credibility once we are dealing with expectations, which is an intangible concept by nature. By adopting such an approach, the reliability of results is dependent on the choice of the proxy variable. Another problem mentioned by the authors is inspired by the well-known Lucas Critique (1976) regarding the assumption of stability of parameters in econometric models; specifically, structural changes may result from modifications in economic policy. As credibility changes over time, it becomes difficult to obtain a dataset that properly describes credibility. Finally, the authors cite the analytical simplicity of existing credibility models as another obstacle to empirical knowledge. They argue that the theoretical constructs are excessively stylized and centered on a few economic variables that are often inadequate for testing. 
These difficulties in dealing with credibility are manifest in the existing empirical studies. Agénor and Taylor (1993), before presenting an approach to measure the credibility of economic policy and its effects, summarize the commonly used procedures. Most of the studies adopt the prediction and error method (for example, Christensen, 1987a; Kremers, 1990) that consists of initially estimating an inflation model (a Phillips curve, for example) up to one period before the implementation of the stabilization measures and applying these estimates to predict the inflation of the post-program period. If the predicted inflation is higher than the actual inflation, the errors in the predictions are seen as evidence that there was a gain in credibility. Blackburn and Christensen (1989) describe two limitations of this procedure. First, the expectations of inflation take some time to adjust to the announcement of regime change, which may render the data used in this type of estimate unable to identify them. Second, the model may simply be misspecified. The errors might reflect any omitted variables; assuming that they necessarily represent credibility is bold.

An alternative to bypass this problem is to explicitly include a proxy variable for credibility in the model (see, for example, Christensen, 1987b; Croushore and Koot, 1991). Agénor and Taylor (1993), in highlighting the critique by Blackburn and Christensen (1989) of this procedure, remind us that the definition of the proxy variable is somewhat arbitrary and does not guarantee that the model captures the effects associated with changes in credibility. In spite of these concerns, they also propose the use of a proxy variable to measure expectations, as they consider it less vulnerable to the limitations associated with the other procedures. Given that the difference between the official and the black market exchange rate is very sensitive to the expectation of the agents in relation to the governmental policies, the authors consider using it to construct a proxy for credibility. The process decomposes the difference into two components: one reflects the "foundations" of the economy, and the other is the basis of the credibility measure. Therefore, variation in the difference would be the result of changes in the "foundations" and in the credibility of the economic policies. The empirical implementation is performed in two steps. First, an autoregressive system is estimated; specifically, the difference is regressed on a predetermined vector of variables that represent the "foundations." The complement of the 
residual of this regression is defined as the credibility variable. ${ }^{2}$ In the second step, using the Kalman filter, inflation is estimated as an autoregressive process with varying parameters. ${ }^{3}$ The coefficient of the autoregressive component varies in accordance with the credibility. If the policy is more trustworthy, the inertial effect on inflation will be lower. The authors used this technique to assess the Cruzado Plan (implemented in Brazil in 1986) and obtained results that can be considered consistent with the historical interpretation of events during the relevant period. The main limitation of this type of procedure is that it demands the use of a time-series sample that is long relative to the period being analyzed to avoid the imposition of numerous restrictions on the credibility variable.

The application of the regression technique with varying parameters to assess credibility fits the variation over time on the expectations of the economic agents. Following this line of thought, Mankiw et al. (1987) assessed the effect of the creation of the Federal Reserve System in 1914 on expectations. The study investigated whether there was a change in the perception of the agents about the environment in which they operated once the system started to function. By examining the relationships between short- and long-term interest rates, under the assumption that the long-term rate incorporates the expectation of the future short-term rate, Mankiw et al. tried to identify changes in the stochastic process that generates the short-term rate, which would alter these relationships. A model with varying parameters was used to determine the most likely date of the change. The authors believe that the results imply that there was an adjustment of expectations under the new economic policy regime defined by the creation of the Federal Reserve System. Although this technique is stronger than those previously proposed, it still uses a proxy variable to represent credibility that is subject to

\footnotetext{
2 This first step is expressed as the system:

$\gamma(L) \rho_{t}=\boldsymbol{\delta}(\boldsymbol{L}) \mathbf{z}_{t}+u_{t}$

$\delta(L)=\delta_{1} L+\delta_{2} L^{2}+\ldots \delta_{n} L^{n}$

$\gamma(L)=1+\gamma_{1} L+\gamma_{2} L^{2}+\ldots \gamma_{n} L^{n}$,

where $\gamma_{i}$ are scale coefficients, $\boldsymbol{\delta}_{i}$ is a vector of coefficients, $L$ is the gap operator, $\rho_{t}$ is the agio, $\mathbf{z}_{t}$ is the vector of the variables that represent the "foundations" and $u_{t}$ is the residual of the process. The credibility variable is defined as $c_{t}=-u_{t}$.

3 The estimate using the Kalman filter is described by the model:

$\pi_{t}=\alpha_{t} \pi_{t-1}+\varepsilon_{t}$

$\alpha_{t}=\alpha_{t-1}+\gamma c_{t}+\eta_{t}$

where $\pi_{t}$ is the rate of inflation in period $t$ and the residuals $\varepsilon_{t}$ and $\eta_{t}$ are not autocorrelated, mean zero, of constant variance and are not correlated with one another.
} 
the limitations mentioned above. An additional difficulty associated with this type of procedure was raised by Agénor and Taylor (1993, p.330): approaches that consider a single point of change, as is true in Mankiw et al., are useful for examining changes in trustworthy and permanent regimes within the period under consideration; however, they are less valuable when credibility is short-lived and may have more than one inflection point.

Thus far, the procedures mentioned all use sampling theory, as found in classical statistics. Another line of procedures attempts to be more loyal to the true spirit of the credibility models by adopting an explicitly Bayesian approach to estimate the expectations of the economic agents regarding the government's commitment to stability. As Baxter (1985, p.348) states, "This problem has a natural Bayesian interpretation as it involves the principle of 'inverse probability', where the data are taken as given and the problem is to try to infer what random process generated them."

The method developed by Baxter (1985) defines credibility as the subjective probability which the agents assign to the government's commitment to the measures of stability, making it a function of the adopted economic policies' parameters. To be credible, a program must feasibly satisfy two conditions that highlight the interaction between the fiscal and monetary sides of the economy: first, the rate of expansion of the money supply must be reduced as announced; second, deficit financing must not imply an explosive trajectory of the public debt levels. It is assumed in the model that the set of all possible governmental policies can be divided into two subsets: one containing the policies that favor stability and the other containing policies that do not favor stability. It is up to the economic agents to assign a certain probability as to whether the regime's economic policy belongs to the set that favors stability. Based on that probability, they can estimate the parameters of the rules of the governmental policy and then predict the future values of the variables. The more observations that are aggregated into the initial stock of information, the more precisely the agents will know the real parameters. In this process of learning by experience, the calculation of the probability that the rules of the governmental policy will belong to the set of measures that lead to stability is made using Bayes' rule, and it is updated with every available new piece of information. 
The measure of credibility proposed by Baxter-adopting Bayes' rule as a way to update the confidence of the economic agents on the commitment of the government to stabilization - is closer to the concept of credibility observed in the models described in the previous section. Therefore, it will be used to estimate the credibility of the economic policy during the Goulart Administrations.

\section{The Goulart Administrations}

After the Vargas suicide in August 1954, the Café Filho (08/1954 to $11 / 1955)$ and the Juscelino Kubitschek (01/1956 to 01/1961) Administrations followed. The latter recorded high growth rates and gave the country an integrated and diversified industrial structure through the Plano de Metas (Plan of Goals), but it also left to its successor, the Jânio Quadros Administration (01/1961 to 08/1961) serious domestic and foreign imbalance. Eight months after taking office, Quadros resigned from the presidency and put the country in one of the most serious institutional crises in its history. The Armed Forces resisted the idea of Vice President João Goulart taking office. Congress did not accept the military's veto. The conflict was bypassed with the adoption of the parliamentary system on September 2 , 1961. Goulart was supposed to remain in office until January 31, 1966; at some point before this date, there would be a referendum on whether to confirm the new regime.

In this volatile political environment, João Goulart took office as president on September 7, 1961. The following day, Tancredo Neves, a member of the PSD (Social Democratic Party), the majority party in Congress, was nominated to the position of prime minister. By the end of 1962, Congress set January 6, 1963, as the date for the referendum that would define the political regime to be adopted. The public voted by a wide margin in favor of a return to the presidential system.

The situation that Goulart inherited was not much different from that inherited by President Vargas ten years earlier. Foreign policy was the only area in which the new administration did not have immediate problems to solve, thanks to the agreements made by the Quadros Administration. Inflation, as calculated by the IGP-DI, had reached 30.5\% in 1960 and was again the main problem to be solved. 
Once more, economic policy was divided between trying to avoid a rise in inflation and maintaining economic growth. The result was a reduction in the rate of economic growth, an acceleration in inflation and a deterioration in the balance of payments, especially between 1961 and 1963.

Overall, the interpretations for the loss of dynamism in the economy either highlight the structural character of the crisis (Furtado, 1968; Tavares and Serra, 1972; Ianni, 1986) in a longer-term view or mention the short-term aspects (Leff, 1977; Wells, 1977), often linking them to the scenario marked by the existing political instability. In general terms, the economic policies are described as indefinite or incoherent. Criticizing Economic Commission for Latin America's (ECLA) structuralism, Simonsen (1969, p. 67-68) writes, "Another example, another specific to Brazil, concerns the decline in the growth rate of the real output between 1962 and 1967. In the view of orthodoxy, this was a reflection of the disequilibrium inherited from the 1950's, of the irrationality of the economic policy between August 1961 and March 1964, and of the further efforts for monetary stabilization." In the view of Baer (1996, p. 87), "the tumultuous years that followed the resignation in the end of August 1961, until the overthrow of the next government in April 1964 were destitute of any consistent path in economic policy." In their analysis of populism in Brazil, Castro and Ronci (1991, p.160-161) remark, "The features of Goulart's populism fit nicely into the description of a conventional mishandling of economic tools." However, a more detailed analysis of the parliamentary and presidential systems during Goulart's term will let us detect a pattern of rationality in the economic policy that is consistent with Barro's model.

\subsection{The Parliamentary Period}

When the first parliamentary Cabinet took office in September 1961, it was faced with a difficult economic situation that was made even worse by the environment of political instability that followed Quadros' resignation. The effort to build a reputation of strong government began with the nomination of a Cabinet in favor of austerity. In the search for a consensus administration, each of the main parties was chosen to be part of the Cabinet in a reasonably balanced share of the ministries. As expected, a conservative minister was 
place in charge of the economy. The Finance Ministry was headed by the orthodox banker Walter Moreira Salles, who was responsible for the successful Brazilian foreign debt negotiation in the United States during the Quadros Administration. Soon after taking office, he emphasized in his speeches the austerity of the economic policy to be undertaken, which would be "carried out through shared decisions of Parliament" (Jornal do Comércio, September 11, 1961, p. 6). He was attempting to distance himself from the presidential figure, although the power of the president was not just symbolic in the Brazilian system; the president was responsible for choosing the prime minister to be submitted for the parliament's approval. It is particularly illuminating to mention the case of the Ministry of Mines \& Energy. For political reasons, its leadership was given to Gabriel Passos, a member of the nationalistic wing of the UDN (National Democratic Union). However, to assuage any concerns from the sector's foreign investors, the new minister soon made assuring declarations through the press; he stated the importance of foreign capital and the role it played in the country's growth. Another ministry worth highlighting is the Ministry of Labor \& Social Security: its leadership was not given to the PTB (Brazilian Labor Party). The PTB was a member and long-time leader of the governing alliance, and this decision clearly demonstrated that the administration wanted to avoid any link with the practices of the old labor party.

Due to the unclear division of power between the president and the prime minister, the government's credibility was largely defined by Goulart's image, both inside and outside the country. Therefore, his early presidential speeches had a moderate tone, undertaking responsibility for democracy, highlighting its opposition to communism, and giving political support to the strictest anti-inflation measures proposed by the Cabinet.

The apparent success of Goulart's trip to the United States in April 1962, manifested in the ratification of the agreements made by the Quadros Administration (although subject to the execution of the stabilization program), served to consolidate his political position domestically, especially within the middle class and the military. However, to stay in power, the administration had to be trusted by the economic agents with respect to its capacity to lead the country toward economic stability. The failure of the first attempt at stabi- 
lization by the first parliamentary Cabinet, consolidated in the so-called "Emergency Action" in September 1961, shook the public's trust in the administration. The measures that were taken did not have the desired effect, and the final months of the year were characterized by a lack of fiscal and monetary control. The truth is that the administration did not immediately possess the tools to address the problems inherited from the previous government; hence, the administration made the decision to concentrate efforts for stabilization on the following year. In January 1962, Moreira Salles, stressed that he would back down and made a plea for the "noble sacrifice" the situation demanded, even as he faced pressures from the business community opposing a possible tax increase and restrictions imposed by the stabilization program (Jornal do Comércio, January $1^{\text {st }}, 1962$, p.8).

The new stabilization program, which was introduced in March 1962, announced goals for a limit on expenditures and on the expansion of money and credit, aiming to reach the economic stability in that year. On the expenditures side, three measures were proposed: a new plan for a limit on expenditures to be sent to Congress for approval, which would save approximately $\mathrm{Cr} \$ 60$ billion; a plan for a budget that outlined payments for supplies and services for the period from January-May 1963, in the amount of Cr\$81 billion; and the transfer of $\mathrm{Cr} \$ 38$ billion in expenditure authorizations to future fiscal years, with no set date of liquidation. Through these measures, the cash deficit would have been reduced to Cr $\$ 150$ billion. In an effort to establish non-inflationary sources for financing the deficit, which was constrained by the constitutional limitation with respect to new tax changes taking effect in the same fiscal year, the government borrowed two sums of funds to cover the difference. One was a compulsory fund of $\mathrm{Cr} \$ 20$ billion, in the form of an additional tax on the income of companies and individuals, and a voluntary fund, estimated at Cr $\$ 100$ billion in Treasury Bills or Obligations with a safety clause against monetary devaluation. The remaining deficit, Cr\$30 billion, was meant to be financed by the Banco do Brasil. Beyond these measures, an administrative tax reform was proposed that was aimed at guiding the economy to equilibrium in the following years. The program stated that the measures to control the public deficit should be complemented by restrictions on credit expansion on the part of the monetary authorities. The loans from the Banco do Brasil to the private sector could not grow more than 
Cr $\$ 35$ billion over the year (nominal increase of roughly $12.7 \%$ ), and the loans made via rediscount were limited to $\mathrm{Cr} \$ 15$ billion. In April, the first month of the program's execution, these goals were met. The public deficit and credit to the private sector stayed within the established limits; however, both figures came dangerously close to the exceeding the set goals.

Although the conditions underlying the implementation of the parliamentary regime resulted from a commitment engendered by that traditionally in power, they led to constant political instability during the parliamentary period. The regime was implemented through a constitutional amendment "worked out in a few hours under the emotional influence of exceptional events" (Brochado da Rocha, apud Abreu, 1989, p.200) and there was constant pressure-first covert, then overt ${ }^{4}$-from President João Goulart to regain full powers traditionally ascribed to his office. Goulart's moves to regain power and his adversaries' responses to prevent him from succeeding only further increased the instability inherent in performing the parliamentary role. This instability contributed to a clear reduction in the decision making horizon of the economic policymakers.

An election for the entirety of the House of Representatives, one-third of the Senate and the governors of half of the states was scheduled for October $7 \mathrm{th}$. The proximity of this election contributed to further confusion in the political environment, increased polarization around the stabilization program and hampered the approval of the necessary but unpopular measures. The members of Congress, including Cabinet members, had no interest in associating their names with the approval of laws that could damage their electoral prospects. This is typically a situation in which the future is strongly discounted, as the option for stability might be had at a cost of at least four years of political ostracism. By mid-May, the legislature had approved only the increase in the percentage of the banks' compulsory deposits. The bills authorizing the compulsory and voluntary loans and the salary increase for federal employees went back to the House, after being amended in the Senate. ${ }^{5}$ The tax reform bill, sent to Congress in November of 1961, would not

\footnotetext{
4 "For fourteen months, from September 1961 to January 1963, Jango carefully manipulated in order to regain presidential powers." (Skidmore, 1976, p.264)

5 These bills were eventually approved by the House of Representatives in June. In the case of the federal employees' salary raise, the amount was equivalent to an increase of approximately $\mathrm{Cr} \$ 94.5$ billion, well above the $\mathrm{Cr} \$ 82$ billion anticipated in the stabilization program.
} 
be analyzed quickly. To make things worse, the degree of political polarization was exacerbated due to arguments about base reforms and the remittance of profits, issues that represented the main conflicting political projects at the time.

The apparent randomization of the economic policy decisions, caused by the government's shortened decision making horizon, the increase in its discount rate over time and the government's rising credibility in its first months (with an associated reduction in the likelihood that the government would continue looking strong), was very clear by May and can be perceived in the confrontation between the monetary and fiscal policies. From this month forward, the government deficit quickly increased, surpassing the goals established by the program. In a contradictory decision, the administration simultaneously adopted restrained credit measures, raising the compulsory deposit through SUMOC's Instruction 225 on May 18, 1962. Another example that reveals the ambiguous posture of the government after May can be observed in Goulart's own behavior. As the popular discontent with regard to the effects of the stabilization program grew, Goulart vacated the position he had taken at the beginning of his term: he abandoned the emphasis on stability to focus on advocacy for base reforms. This behavior progressed steadily, as seen in two speeches. On May 1, still using moderate language, Goulart advocated the need for constitutional changes that would permit the expropriation of land for land reform purposes, payable in bonds and not in cash. In an address to longshoremen on May 14, Goulart was much more incisive, stressing his links with Vargas' trabalhismo and preaching the necessity of reforms to assure the economic emancipation of the country, with a particular emphasis on land reform. Additionally, the president denied any responsibility for the economic situation of the country, instead blaming the Cabinet for the difficulties the population was experiencing.

The effect of the administration's change of attitude toward stability measures can be observed in the figures of the main political variables. In May, the government exceeded the limit projected for the public deficit and, consequently, the limit of credit from the Banco do Brasil to the Treasury. In that month, the credit to the private sector still remained within the limits that were set in the program. Nevertheless, as noted by Abreu (1989, p.203), "the lack of control over the economy becomes evident as of May with the significant 
increase in the government's cash deficit produced by the raise in public expenditure and the raise in the expansion rate of the money supply." The month of June, the last of the Neves Cabinet, marked the full renunciation of the stabilization policy. In that month, the public deficit rose to a level more than double that which had been set as the annual goal and the limit of the nominal credit from the Banco do Brasil to the private sector was exceeded. This series of events destroyed what remained of the government's credibility.

At this stage, the lack of credibility made any new attempt for stabilization impossible. The new Cabinet, led by Brochado da Rocha, made some efforts, but the odds of success were minimal. The fiscal, monetary and credit limits were exceeded. Furthermore, the referendum to decide the political system hampered any potential stabilization endeavors by rendering the government temporary. Moreira Salles stepped aside in September of 1962; he was exhausted by the conflicts between the measures he tried to implement and the speeches of the president, other administration officials and their support base in Congress. These speeches had a strongly nationalistic tone, supporting the expropriation of the Telephone Company of Rio Grande do Sul (a subsidiary of an American company) and a bill limiting the remittance of profits abroad, which was approved by the Senate in early June shortly before the approval of the National Council for Land Reform.

The year of 1962 ended with a high GDP growth rate (6.6\%) - although inferior to that of 1961 (8.1\%) - an inflation rate of $51.6 \%$ and a negative trade balance of 89 million dollars; the change in the trade balance was mainly a result of a fall in exports (from US\$ 1,405 million to US $\$ 1,215$ million), as imports increased only slightly (from US\$1,292 million to US\$1,304 million). By the end of the year, Goulart blamed the IMF for these difficulties; in particular, he cited the conditions the IMF imposed on the Latin American economies (Jornal do Comércio, December 6, 1962, p.6).

\subsection{The Presidential Period}

After regaining full powers in January 1963, Goulart faced the difficult challenge of regaining the trust of the economic agents in terms of his capacity (and will) to solve the serious problems the country 
was facing; worse, these problems were partly deepened by his own actions during the parliamentary period. Once more, in view of the fragile structure of the country's economic institutions, the attempt toward stabilization was laid on a delicate framework: the nominations of the ministers. Goulart tried to choose a ministry made of eminent personalities, and moderation was a key requirement. San Tiago Dantas was appointed Finance Minister. Although a member of the left wing of PTB, the new minister was known for his advocacy of orthodox ideas in fighting inflation. In the economic arena, Celso Furtado was a minister without a ministry; he was not linked to any political party and was responsible for the economic planning and for managing SUDENE. The hard-line leftists were represented by the Minister of Labor, Almino Afonso, and by the ultranationalist João Mangabeira, who was in charge of the Ministry of Interior \& Justice. These appointments were an indication that Goulart was not willing to separate himself completely from his ties with the unions. The Ministry of Defense continued in the hands of General Amauri Kruel, a moderate.

The first measures of this new phase of the Goulart Administration were codified in the Triennial Plan. The plan tried to reissue the old Campos Salles - Rodrigues Alves "formula", emphasizing the commitment to the economic development that would have short-run stability as a prerequisite; without stability, the growth goals themselves would be jeopardized. Therefore, the Triennial Plan intended to execute typical restraining policies from conventional stabilization programs such as reduction of the public deficit, control of money issuance and restraints on credit to the private sector. Additionally, it proposed making the exchange rates uniform and fixing them within a realistic range. To demonstrate the seriousness of its intentions, the administration set fiscal and monetary goals that were to be fulfilled throughout the year. Once again, the behavior from the parliamentary period was repeated: strong measures to fight inflation were announced as a way for the government to build its reputation as strong on inflation.

The outcome was reasonably positive in the first months. The currency devaluation in April nearly drove the official exchange rate to the parallel market rate, which showed a change in the level of public trust in the government. The goal for the public deficit was not fulfilled in the first quarter because the norms of financial execution 
were established only in March; however, in the second quarter, the administration did not violate the limit. Although the government did not achieve the fixed nominal goals of the credit policy, the policy was restrictive in real terms in the first two quarters: in the first quarter, real credit shrank almost $17 \%$. In the second quarter, the reduction was approximately $4 \%$. The rise in prices, after the corrective inflation of the first months, slowed in April, which signaled the possibility of success for the stabilization program.

Despite the easy victory in the referendum, the political situation in the beginning of Goulart's presidential administration was not calm. Radicalization of the public continued and the government's stability depended on Goulart's capacity to calm the conflicting groups. Skidmore (1976) highlights the two disputing sides: the traditional anti-Vargas faction led by Carlos Lacerda and the radical left led by Leonel Brizola. According to Skidmore, the impossibility of a commitment policy emerged most clearly in the controversies over foreign capital and land reform.

Thanks in part to both groups, the threat of a coup loomed during the whole term and was finally realized in March 1964. The hard-line right-wingers had conspired against Goulart even before Quadros' resignation; there had been resistance since his time as a minister under Vargas. Now better organized, they were able to garner the decisive support of the Social Studies and Research Institute (IPES), an organization founded in November 1961 by businessmen from Rio de Janeiro and São Paulo who opposed Goulart's guidelines. Such strong support strengthened the conspiracy movement which already admitted to the "use of more direct methods" to resist the government. The radical leftists likewise left open the possibility of "direct methods to fight the 'coup advocates', 'betrayers' and 'reactionaries'” (Skidmore, 1976, p.275-276, marks by the author). The imminent possibility of a coup contributed to the reduction of the temporal horizon of the government's decision making and to increase its discount rate. A move by Goulart in either direction could have meant the end of the government by means of a coup on the part of the neglected group. Such a move occurred by the end of 1963 when Goulart sided with the radical left in an effort to stay in power; this marked a shift in his handling of economic policy. 
The economic difficulties associated with the costs of the stabilization program combined with the progressive deterioration of political conditions to deepen the ongoing political radicalization. The measures of fiscal and monetary discipline, which were necessary for the stabilization effort, were interpreted by the nationalists as a requirement imposed by the developed countries to suit their interests at the expense of the Brazilian population. The corrective inflation that followed the readjustments of the exchange rate and public utility prices and the government's tight credit policy made the government even more vulnerable to criticism by the opposition. At this moment, one could say that the cost of adjustment neared to the cost of inflation and the administration became indifferent between the alternatives.

The government's change in attitude toward stability that marked the beginning of the stage of economic policy randomization first surfaced during the civil servant salary readjustment in May. In agreeing to a readjustment of $70 \%$ one week after the IMF visited the country, the administration knew it was jeopardizing the central commitment of the stabilization program. Although the May and June financial reprogramming kept the deficit at approximately the same level that was forecast in the initial program, the administration's move cast doubt on its capacity to support fiscal discipline. From the perspective of monetary policy, tight credit was still imposed by SUMOC's Instructions 234 and 235. ${ }^{6}$ Once more, we observe the lack of harmony between the government's fiscal and monetary policies. The main economic variables in the third quarter confirm the contradictory nature of the economic policy executed. The goal for the public deficit was surpassed by over $100 \%$; in contrast, the credit to the private sector, while not respecting the nominal limits anymore, remained stagnant in real terms. The ambiguity of the economic policy is stressed by Lessa (1982, p.134): "However, although in the second half of 1963 the fiscal, exchange and monetary policies did not comply with the Triennial Plan, exceeding their projections, there were still attempts of conjoined formulation of the short-run policies, which were unfortunately

6 Through Instruction 234, enacted February 14, quarterly limits of expansion were fixed for the Department of General Credit and the Department of Agricultural \& Industrial Credit. Instruction 235, enacted March 7, set the limits of the credit operations according to the programming of the Triennial Plan and measures of selective control of investments, with credit priority bands. In addition, it increased the percentage of the compulsory deposits from 20 to $28 \%$ for in-cash deposits, and from 7 to $14 \%$ for installment deposits. 
not very successful". The problem is that the nonfulfillment of the goals eroded the government's credibility, pushing the economy to the discretionary equilibrium.

One of the last attempts to a short-run stabilization was SUMOC's Instruction 255, by which the banks that surpassed the government's authorized credit limits would be required to buy Treasury bonds, without interest, with a discharge term of 180 days. This measure was proposed by Carvalho Pinto, the second Finance Minister under Goulart. By choosing a conservative politician who had good relations in the business environment in São Paulo, Goulart tried to foster an image of moderation, meaning he would not abandon his pursuit of credibility. However, as Pinto took office, he made it clear that his policies would alter the government priority regarding stabilization; it should be pursued, but it would have to be compatible with the search for short-run growth. The most popular newsmagazine of the time, O Cruzeiro, reported this as a positive fact: "Mr. Carvalho Pinto intends to discipline the finances, but will soften the controls fixed by his antecessor promoting some items of the development program. His name commands confidence to the ruling classes and calms São Paulo, so restless of late as a result of the direction of the government" (July 13, 1963). By doing so, the minister looked for more social support, but especially tried to synchronize his speech with the president's; in a previous issue, O Cruzeiro reported that when Goulart chose his Cabinet, he "Had serious thoughts about the possibility of making public constructions and opening new job opportunities in the many areas of the country." Additionally, "despite the danger" of a rise in inflation, the option "offered the best advantages from the political point of view" (July 6, 1963). On the same day as the enactment of Instruction 255, populism ceased to be a vague voice looking for legitimacy; repercussions abroad were so high that Roberto Campos, the Brazilian ambassador to the United States, resigned from his post because he considered "the possibilities of credit to Brazil totally lost, after the cabinet changes made to alter the financial recovery policy." In August, Businessweek magazine reported that Goulart had abandoned the inflation-fighting policy altogether.

The revocation of SUMOC's Instruction 255 after only two months - when the economy was already under the third Finance Minister, Nei Galvão-marks the passing of the handling of the 
economic policy to the discretionary equilibrium phase, when the administration no longer had public credibility. In Skidmore's words (1976, p.326): "the death-knell was tolled when Carvalho Pinto left the Finance Ministry by the end of December. One of the first actions of his successor was to agree with the revocation of SUMOC's Instruction 255, thus putting down the last resource to finance the dying Triennial Plan.” By December, no more references were made to the goals set in the early months. By the end of 1963, the deficit was $50 \%$ above the forecast and the tightening of credit was reversed.

\section{Credibility in the Goulart Administrations}

To support the hypothesis that the credibility played a fundamental role in the way economic policy was conducted during the Goulart Administrations, we estimate the credibility of these policies using a Bayesian approach. Following Baxter (1985), in the empirical implementation of this credibility model, it is assumed that the governmental policies can be described using a linear multiple regression model:

$$
y=X^{\prime} \theta+u,
$$

where $y$ is the policy's variable, $X$ is a vector of state variables, $\theta$ is a vector of regression coefficients and $u$ is the error term, assumed to be i.i.d. (independently and identically distributed) and normally distributed with mean zero and variance $\sigma^{2}$. When a new economic policy regime is proclaimed at $t=0$ to be enacted as of $t=1$, the agents possess prior beliefs about the real future value of $\boldsymbol{\theta}$ and $\sigma$; these beliefs are summarized by a prior probability density function $f(\boldsymbol{\theta})$. Through Bayes' rule, this prior function is combined with the sample information obtained after the proclamation of the measures, represented by a likelihood function, $f\left(y_{t} \mid \theta\right)$. This combination yields the posterior probability density function $f\left(\theta \mid y_{t}\right)$. Credibility then is defined as the posterior probability assigned by the agents to the event that the economic policy belongs to the set of measures that lead to stability. At time $t$, it will be:

$$
C_{t}=\int_{\theta \in R} f\left(\theta \mid y_{t}\right) d \theta,
$$


where $f\left(\theta \mid y_{t}\right)$ is the marginal posterior probability density function for $\theta$, given the vector of observations of the variable for policy $y_{t}$, and $R$ is the set of measures that favor stability.

According to Baxter (1985), there are two conditions that must be satisfied for a stability program to be trustworthy: the rate of expansion of the money supply should adhere to what was announced and deficit financing should occur under conditions that do not imply an explosive trajectory of the public debt level. These conditions can be expressed by two rules under the assumption of a fixed exchange rate. The monetary policy rule is given by:

$$
D C_{t}=\left(1+\theta+\varepsilon_{t}\right) D C_{t-1},
$$

where $D C_{t}$ is the level of domestic credit, $\theta$ is the target for the credit growth rate and $\varepsilon$ is the error, with mean zero and $\sigma_{\varepsilon}^{2}$ variance. Assuming the equality between the domestic inflation rate $\pi$, and the foreign inflation rate $\pi^{*}$, the monetary authority must keep $\theta \leq$ $\pi^{*}$ to prevent an excessive money supply. This guideline ensures that the exchange rate remains at the established level and that inflation is reduced. The fiscal policy rule is given by:

$$
D_{t}=\alpha_{0}+\alpha_{1} B_{t-1}+u_{t},
$$

where $D_{\mathrm{t}}$ is the real value of deficit minus the debt service at time $\mathrm{t}, B_{t-1}$ is the real value of the governmental debt stock in period $t-1$, and $u_{t}$ is the error with mean zero and $\sigma_{u}{ }^{2}$ variance. The budget constraint of the government is given by:

$$
D_{t}=B_{t}-(1+r) B_{t-1}+\left(D C_{t}-D C_{t-1}\right) / p_{t},
$$

where $r$ is the real interest rate which is assumed to be constant, and $p_{t}$ is the level of prices in $t$.

Combining Equations (14) and (15), we obtain:

$$
B_{t}=\alpha_{0}+\gamma B_{t-1}-\left(D C_{t}-D C_{t-1}\right) / p_{t}+u_{t},
$$

where $\gamma=\left(1+r+\alpha_{1}\right)$. The necessary condition such that the governmental debt does not have an explosive trajectory is $\gamma<1$ because, in that case, $\alpha_{1}<-r$. From Equation (15), this condition 
ensures that at each period the government reduces part of the total of its debt.

According to Rocha (1997), under a flexible exchange rate regime, the change in domestic credit is the change in the money supply. Therefore, the monetary policy rule is given by:

$$
M B_{t}=\left(1+\theta+\varepsilon_{t}\right) M B_{t-1},
$$

where $M B_{t}$ is the monetary base in $t, \theta$ is the rate of growth of the monetary base and $\varepsilon$ is the error, with mean zero and $\sigma_{\varepsilon}^{2}$ variance. The monetary restraint requires that $\theta \leq 0$, which results in a restrictive monetary policy and assures a decline in inflation in the long term. The fiscal restraint is similar to the one described by Baxter, except that we replace the level of domestic credit with the monetary base.

In the case of Brazil in the early 1960s, it did not make sense to apply the restraint to fiscal policy as there was no public bonds market. The absence of this market forced the government to turn to loans from Banco do Brasil as its primary and near-exclusive source of financing for any excessive expenditure. The peculiar position of Banco do Brasil in the financial system deserves a special explanation because of the implications it has on the money supply. At the time there was no true central bank, ${ }^{7}$ and the role of monetary authority was share by Superintendência da Moeda e do Crédito (SUMOC) and Banco do Brasil. The former was in charge of decisions regarding currency and credit, while the latter administered the execution of those decisions. By combining the roles of commercial bank and financial agent of the monetary authorities, Banco do Brasil gained the ability to expand the monetary base through the expansion of its deposits. Under these circumstances, credibility should be measured based on monetary policy rule under a flexible exchange rate regime.

The Bayesian estimates of the model were derived from Equation (18) using data on the real monetary base (deflated by IPA-DI). We used SHAZAM software version 8.0. Following Geweke's (1986) methodology, a prior distribution with inequality constraints was used to generate probability values from the posterior distribution. These values were used as a measure of credibility of the monetary

7 The creation of Banco Central da República do Brasil occurred in December 1964. 
policy, as given by Equation (13). To calculate the probability, the program uses a Monte Carlo numerical integration procedure which is implemented by generating replications from a multivariate $t$ distribution. The antithetic replication process changes the sign of the vector of random numbers. The procedure essentially operates by artificially generating samples from a posterior probability density function. The proportion of the observations that obey the restraint (in this case, $\theta \leq 0$ ) is the estimate of probability. The estimates of the probability incorporated the information from the six months prior to each month under study across 200,000 artificial samples $(100,000$ antithetic). The results are given in the chart below.

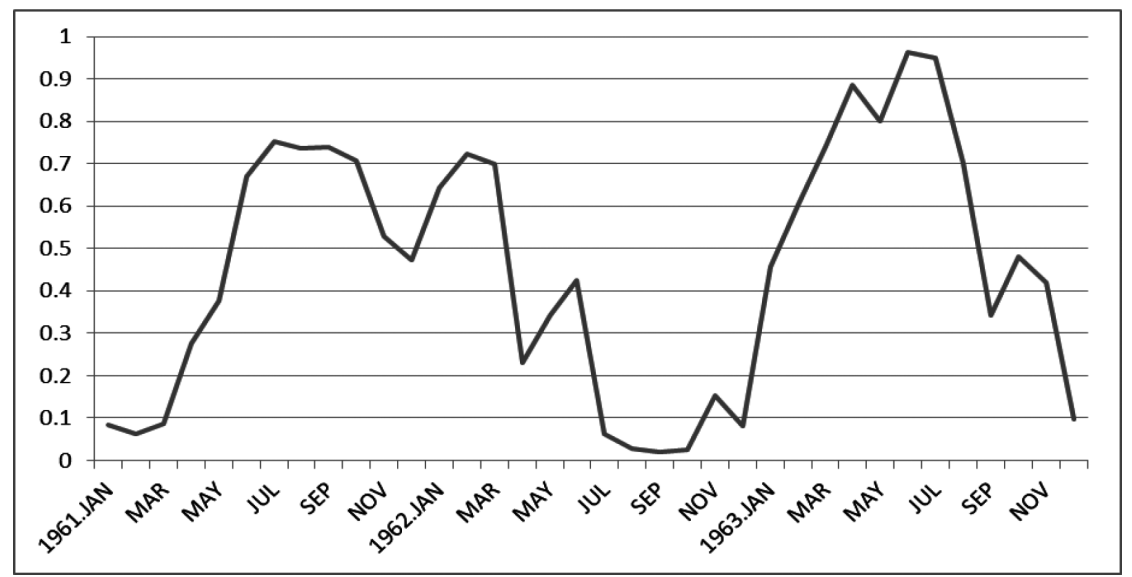

Credibility of monetary policy: Brazil (1961-64)

The measure of credibility of the monetary policy shows that the Jânio Quadros Administration (January 1961 to August 1961) started with a credibility slightly greater than $8 \%$ in January 1961. The following months were characterized by a constant increase in credibility thanks to a commitment to stabilization; this effort was represented by the reform in the exchange system sealed by SUMOC Act 204 in March 1961. After Quadros left office, the government's credibility started to decrease.

During the parliamentary period (September 1961 to December 1962), there was an initial attempt to promote stabilization by the first Cabinet led by Tancredo Neves; this effort culminated in the so-called "Emergency Action." These measures were not effective, 
and the last months of the year reflected a loss in credibility. There was a slight gain in credibility as new measures were announced in 1962, but the frailty of the political framing caused credibility to generally decrease. In June, the first Cabinet resigned; the following month, credibility fell to approximately $6 \%$. The new Cabinet, led by Brochado da Rocha, sketched a new attempt promote to stabilization, but it was destined to fail. The temporary nature of the government, created by the demand to move the referendum determining the system of government to an earlier date, prevented the government from persevering in this effort. In September, the month of the resignation of the second Cabinet, credibility reached its lowest level (less than 2\%). Finally, the next Cabinet, led by Lima, completely submitted to its temporary nature: it acted only to try to prevent the worsening of the economic situation.

In 1963, the presidential government of João Goulart showed impressive gains in credibility. These gains were supported by the Triennial Plan, which was decidedly orthodox. The results from the first months are fairly encouraging. In April, an exchange rate devaluation that nearly equalized the official exchange rate and the black market rate reflected a change in the level of trust in the government. At that point, the government's credibility nearly reached $88 \%$. The public debt goal was not reached in the first quarter because the norms of financial execution were established only in March; however, in the second quarter, the government managed to stay within the established limit. The credit policy, although it did not meet the fixed nominal goals, achieved contractions in real terms in the first two quarters. In the first quarter, real credit was reduced by nearly $17 \%$. In the second quarter it shrank by approximately $4 \%$. The rise in prices after the corrective inflation of the first months slowed in April, signaling the possibility of success of the stabilization program. In June, credibility reached its highest level at approximately $96 \%$.

Nevertheless, the economic difficulties associated with the costs of the stabilization program were accompanied by the progressive deterioration of political conditions and the increased radicalization of competing positions. The tight credit policy and the corrective inflation that followed the readjustments of the exchange rate and public tariffs made the government very vulnerable to the critiques of its opponents. 
The social costs of maintaining a recessive policy led to the government sending ambiguous signals concerning its commitment to stabilization. In the third quarter, the public deficit goal was exceeded by over $100 \%$. This quarter marked the beginning of a progressive loss of credibility. According to Skidmore (1976, p. 326): "The final blow happened when Carvalho Pinto lost his position as Treasury Minister in late December. One of the first actions of his successor was to agree with the revocation of SUMOC's Act. $255,{ }^{8}$ thus avoiding financing the almost dead Plano Trienal." In December, credibility fell below 10\%; at this point, the political and economic conditions already foreshadowed the institutional rupture that would happen in the ensuing year.

\section{Conclusion}

The analysis of the economic policy of the two political periods being studied, known as "populist" governments in the literature, follows a certain pattern that is highly similar to the model proposed by Barro (1986). This model is based on the governmental dilemma between lowering inflation and speeding up growth and stylizes the interaction between the government and the private sector as a repeated non-cooperative game of incomplete information and finite duration. We do not mean to say that Barro's model is the only explanation for the observed phenomenon. The sequence of events was certainly more complex in its economic, political and institutional determinants. Additionally, external restrictions certainly influenced economic policy; including them in the analysis aids a broader explanation of the impasses and the sequencing of the three phases in each of the scenarios examined. However, it seems undeniable that the model questions certain interpretations of the economic policies implemented in these periods. Therefore, it helps to shed light on new angles that contribute to a better understanding of the way populism expresses itself in matters of economic policy.

There is a clear sequence of three phases in the two periods analyzed. Although determining the exact boundaries of the pha-

\footnotetext{
8 In October, facing the fast growth of the public deficit, then Minister Carvalho Pinto proposed a system of non-inflationary financing through SUMOC's Act.255. It stated that the banks that exceeded the authorized limits of credit would be forced to buy Treasury bonds, with no interest under a 180-day discharge term.
} 
ses is a controversial task, it seems without question that the first phase of each period started with the advocacy of the need for stabilization policy; importantly, this phase was also characterized by a strong rhetorical emphasis on the need for long-term economic development. In both of the periods, we see that the economic team and the presidency adopted a style of communication advocating austerity, trying to convince the economic agents that stabilization was a priority. Therefore, it is not reasonable to claim that "populist" governments are unable to embrace pro-stability practice or speech: the initial phase of each period displayed an emphasis on orthodoxy, both in rhetoric and in the handling of economic policy. The existence of this initial stage, where orthodoxy dominates, contrasts with the sequence of stages proposed by Dornbusch and Edwards (1990) to describe the populist paradigm.

The next phase was characterized by the inability of the administration in maintaining this emphasis. This shift could have been due to the fragility of the political support base in moments of crisis, as was the case during the Goulart Administrations. In both periods, there was an oscillating policy or randomization phase characterized by temporary policies. One interpretation of this phase suggests that the governments themselves were not willing to completely discard the initial stabilization proposal when faced with pressure. Instead, they gradually backed away by proposing isolated growth policies and loosening goals without immediately abandoning the stabilization perspective; perhaps they were trying to make the two approaches compatible, which was a fruitless attempt because this signaled their sensitivity and vulnerability to external demands. In other words, they demonstrated their weakness in the handling of economic policy. This exposure created an environment that fostered the intensification of inflation and the further fragmentation of their support base. Faced with these difficulties, the government entered the third phase: they placed a priority on growth, even at the cost of higher inflation.

In light of these observations, the literature's approaches to analyzing these governments and understanding populism in terms of economic policy may be brought into question. We may delineate several implications of our analysis. First, there is a certain logic and coherence in the economic policies implemented that cannot therefore be considered irrational or erratic. Second, orthodoxy is present both 
in the speech of the government and in its actual implementation of the policies, especially in the first phase of each of the periods, which precludes characterizing the populist phenomenon as exclusively promoting growth and disregarding stability. Third, despite its availability, the option to seriously fight inflation was not maintained throughout either of the analyzed periods. Fourth, the transition between the focus on stability and the focus on growth was never abrupt; this gradual transition does not support theses that mention a discrete "shift" that could serve as a landmark separating the two opposing economic policies. Fifth, pro-development rhetoric was present in the three phases of each of the analyzed periods, but only in the final phase was growth set as a priority to the complete exclusion of stability. Sixth, the pro-development speech in these final phases took a rather critical, almost nationalistic, tone. The administration usually blamed foreign capital and international organizations for the deepening of the crisis, taking a radical tone not observed in the first stages.

In an attempt to reconcile conflicting interpretations in the literature about the economic policies of these administrations, we note that previous authors emphasized aspects specific to each phase and generalized them to the whole, in search of a more comprehensive approach. Thus, the authors who emphasized the erratic and irrational character of the policies certainly found their evidence in the randomization phase, and those who emphasized the nationalistic and pro-development character found support in the last phase. However, we may infer that the "populist economic policy" cannot be reduced to any of the phases; in isolation, each phase is unable to help untangle such a complex phenomenon. Populism can be better understood using the repetitive three-stage pattern revealed in this paper. In analyzing the evolution of the events, that is, in modeling policy as an interaction between government and the other agents, we can distinctly detect a consistent logic in the handling of economic policy that we might call populist. This logic arises in light of concrete and historically determined experiences. 


\section{References}

ABREU, M. de P., A ordem do progresso: cem anos de política republicana, 1889-1989. (Rio de Janeiro, 1989).

AGÉNOR, P. R.; Taylor, M. P., Analysing credibility in high-inflation countries: a new approach. The Economic Journal, v.103 (1993).

BAER, W., A economia brasileira. (São Paulo,1996).

BANDEIRA, M., O governo João Goulart: as lutas sociais no Brasil (1961-1964). (Rio de Janeiro, 1983).

BARRO, R., 'Reputation in a model of monetary policy with incomplete information'. Journal of Monetary Economics, 17(1986), pp. 1-20.

BASTOS, P. P. Z., O plano Trienal e sua economia política. In: O Plano Trienal e o Ministério do Planejamento. (Rio de Janeiro, 2011).

BAXTER, M., The role of expectations in stabilization policy. Journal of Monetary Economics, v. 15, (1985).

BLACKBURN, K.; Christensen, M., Monetary policy and policy credibility: theories and evidence. Journal of Economic Literature, v.27 (1989).

Boletim Mensal da SUMOC, 1961-1964. Brasília.

BRASIL, Presidência da República. Plano Trienal de Desenvolvimento Econômico e Social: 1963-65. (Departamento de Imprensa Nacional, 1963).

CASTRO, P.R., Ronci, M., 'Sixty years of populism in Brazil.' In: Dornbusch, R., Edwards, S. The macroeconomics of populism in Latin America. (Chicago, 1991).

CHRISTENSEN, M., Disinflation, credibility and price inertia. Applied Economics, v.19 (1987a).

., On interest rate determination, testing for policy credibility, and the relevance of the Lucas critique. European Journal of Political Economy, v. 3 (1987b).

Conjuntura Econômica, 1961-1964. Rio de Janeiro, Fundação Getúlio Vargas.

CROUSHORE, D.; Koot, R. S., A measure of Federal Reserve credibility. Working Paper, n. 91-1 (Federal Reserve Bank of Philadelphia), 1991.

DORNBUSCH, R., Edwards, S., The macroeconomics of populism in Latin America. Journal of Development Economics, 32 (1990), pp. 247-277.

., Edwards, S., The macroeconomics of populism in Latin America. (Chicago, 1991).

FONSECA, P. C. D., Vargas: o capitalismo em construção, 1906-1954. (São Paulo, 1989).

., Legitimidade e credibilidade: impasses da política econômica do governo Goulart. Estudos econômicos, v. 34, n. 1(2004), pp. 587-622.

FURTADO, C., Um Projeto para o Brasil. (Rio de Janeiro, 1968).

GEWEKE, J., Exact inference in the inequality constrained normal linear regression model. Journal of Applied Econometrics, v.1 (1986).

IANNI, O., Estado e Planejamento Econômico no Brasil. (1930-1970). (Rio de Janeiro, 1986).

IBGE. Estatísticas históricas do Brasil. (Rio de Janeiro, 1990).

Jornal do Comércio, 1961-64. Porto Alegre.

KREMERS, J. M., Gaining policy credibility for a disinflation. Staff Papers (International Monetary Fund), v.37 (1990).

LEFF, N. H., Política Econômica e Desenvolvimento no Brasil: 1947-1964. (São Paulo, 1977).

LESSA, C., Quinze anos de política econômica. (São Paulo, 1982).

LOUREIRO, F. P., Empresários, Trabalhadores e Grupos de Interesse: a Política Econômica nos Governos Jânio Quadros e João Goulart, 1961-1964. (Tese de Doutorado, FFLCH/USP, São Paulo 2012) 
LUCAS, R., Econometric policy evaluation: a critique. Journal of Monetary Economics (Conference Series on Public Policy, 1976).

MANKIW, G., et al. The adjustment of expectations to a change in regime: a study of the founding of the Federal Reserve. American Economic Review, v. 77, n.3 (1987).

O CRUZEIRO, 1963. Rio de Janeiro.

RELATÓRIO ANUAL da SUMOC, 1961-64. Brasília.

PERSSON, T.; Tabellini, G., (eds.). Monetary and fiscal policy. (Cambridge, 1994).

ROCHA, F., Monetary reform credibility: some evidence for Brazil. Estudos Econômicos, v.27, n.3, (1997).

SIMONSEN. M. H., Brasil 2001. (Rio de Janeiro, 1969).

SKIDMORE, T., Brasil: de Getúlio a Castelo. (Rio de Janeiro, 1976).

TAVARES, M.C. e Serra, J., Mais Além da Estagnação: Uma Discussão sobre o Estilo de Desenvolvimento Recente no Brasil. (n.p., 1972).

WELLS, J.R., 'Growth and Fluctuations in the Brazilian Manufacturing Sector during the 1960's and Early 1970's'. (unpub. Diss., University of Cambridge, 1977). 


\section{Appendix 1: Basic Mensal Data}

\begin{tabular}{|c|c|c|c|}
\hline Month & $\begin{array}{l}\text { Nominal monetary } \\
\text { base (million Cr\$) }\end{array}$ & $\begin{array}{c}\text { Inflation index - IPA-DI } \\
(03 / 86=100)\end{array}$ & Real monetary base $(\div 10.000)$ \\
\hline 07/1960 & 269514 & 0.0004393 & 61351 \\
\hline 08 & 282114 & 0.0004609 & 61209 \\
\hline 09 & 299768 & 0.0004783 & 62674 \\
\hline 10 & 311506 & 0.0005030 & 61930 \\
\hline 11 & 327938 & 0.0005156 & 63603 \\
\hline 12 & 364780 & 0.0005270 & 69218 \\
\hline 01/1961 & 377525 & 0.0005384 & 70120 \\
\hline 02 & 381114 & 0.0005366 & 71024 \\
\hline 03 & 392687 & 0.0005493 & 71489 \\
\hline 04 & 390842 & 0.0005793 & 67468 \\
\hline 05 & 391725 & 0.0005877 & 66654 \\
\hline 06 & 403881 & 0.0006015 & 67146 \\
\hline 07 & 406357 & 0.0006069 & 66956 \\
\hline 08 & 438045 & 0.0006430 & 68125 \\
\hline 09 & 463302 & 0.0006754 & 68597 \\
\hline 10 & 486522 & 0.0007464 & 65182 \\
\hline 11 & 517507 & 0.0007788 & 66449 \\
\hline 12 & 545508 & 0.0008070 & 67597 \\
\hline 01/1962 & 546831 & 0.0008401 & 65091 \\
\hline 02 & 558493 & 0.0008563 & 65222 \\
\hline 03 & 569533 & 0.0008623 & 66048 \\
\hline 04 & 593310 & 0.0008641 & 68662 \\
\hline 05 & 613166 & 0.0008972 & 68342 \\
\hline 06 & 631128 & 0.0009212 & 68512 \\
\hline 07 & 678450 & 0.0009663 & 70211 \\
\hline 08 & 707553 & 0.0009831 & 71972 \\
\hline 09 & 756811 & 0.0010070 & 75155 \\
\hline 10 & 831087 & 0.0010370 & 80143 \\
\hline 11 & 857301 & 0.0011170 & 76750 \\
\hline 12 & 955422 & 0.0011750 & 81313 \\
\hline 01/1963 & 939834 & 0.0012910 & 72799 \\
\hline 02 & 953086 & 0.0013800 & 69064 \\
\hline 03 & 975474 & 0.0014650 & 66585 \\
\hline 04 & 978149 & 0.0014720 & 66450 \\
\hline 05 & 1040442 & 0.0015400 & 67561 \\
\hline 06 & 1065915 & 0.0016360 & 65154 \\
\hline 07 & 1084011 & 0.0016800 & 64524 \\
\hline 08 & 1165890 & 0.0017490 & 66660 \\
\hline 09 & 1270506 & 0.0018550 & 68491 \\
\hline 10 & 1315401 & 0.0019680 & 66839 \\
\hline 11 & 1399576 & 0.0020360 & 68741 \\
\hline 12 & 1613455 & 0.0021520 & 74975 \\
\hline
\end{tabular}

Sources: SUMOC Annual Reports (1961-1964) and Conjuntura Econômica (1961-1964) 